Digital Press Social Sciences and Humanities

Training Program on Developing HOTS's Instrument (The Improving Abilities for Elementary School Teachers)

Syafri Ahmad, Refiona Andika, Sherlyane Hendri and Ary Kiswanto Kenedi

Proceeding of The Non-Formal Education International Conference 2020

Alim Harun Pamungkas, Jamaris, Solfema (eds) 


\title{
Training Program on Developing HOTS's Instrument (The Improving Abilities for Elementary School Teachers)
}

\author{
Syafri Ahmad*, Refiona Andika, Sherlyane Hendri, and Ary Kiswanto Kenedi \\ Department of Primary Teacher Education Universitas Negeri Padang, Padang, Indonesia \\ *e-mail: syafriahmad@fip.unp.ac.id
}

\begin{abstract}
Many teachers were unable to write HOTS questions based on the outlines for elementary school students. This resulted in many students being unable to answer HOTS questions because the questions developed were difficult, not following the HOTS category. The purpose of this training is to improve the ability of elementary school teachers to write HOTS questions. This training method is a participatory method using a lecture approach and direct guidance. The result of this training is to increase the teacher's knowledge from the teacher's initial ability of 63.76 to 87.65. Besides, teacher skills also increased from basic skills with a score of 56.95 to 85.35 . In conclusion, the training provided can improve the knowledge and skills of teachers in writing HOTS questions. The implication of this training is as a reference in improving the ability to write HOTS questions for elementary school teachers.
\end{abstract}

\section{Keywords}

training program, developing hots's instrument

\section{Introduction}

Higher-order thinking skills (HOTS) are thinking skills that do not use the usual thinking process. HOTS is a person's ability to think beyond what is usually done (Ahmad et al, 2017; Merta Dhewa et al, 2017). HOTS is the thinking ability owned by individuals in analyzing, assessing, and creating something as a process of solving problems (Widana, 2017; Kenedi, 2018). HOTS can become the ability to think critically and creatively to conclude a problem (Ahmad et al, 2018; Yuliati, 2018). So, HOTS is an ability that requires students to think beyond their general thinking ability.

HOTS needs to be developed in the Industry 4.0 era (Zaharin et al, 2018). HOTS can facilitate students in thinking critically and creatively by using the ability to analyze, assess, and create a process of concluding and solving problems. Teachers must develop it now to help students face various more complex problems in the future. They need HOTS in solving these problems. Therefore, HOTS needs to be developed in the learning process including mathematics learning in elementary schools.

Mathematics learning must be taught in elementary schools (Kenedi et al, 2019). Mathematics learning is useful in developing HOTS for elementary school students (Pratama and Retnawati, 2018). The alignment of mathematics learning objectives in elementary schools with the essence of HOTS is in line. Mathematics in Primary school aims to develop critical, systematic, logical, and analytical thinking skills of elementary school students through understanding the concepts (Ahamad et al, 2019; Kenedi et al, 2019). From these objectives, learning mathematics in elementary schools indirectly develops the HOTS of elementary school students. So, learning mathematics in elementary schools is a must.

In 2018, the Ministry of Education and Culture launched a program that supports the implementation of HOTS, namely a learning program oriented to higher-order thinking skills (Ariyana et al, 2018). This is based on the results of PISA and TIMSS which prove that Indonesia is always ranked below the world, including in mathematics (Priyani and Ekawati et al, 2018). Therefore, to overcome these problems the government through the ministry of education and culture has intensified this program since 2018.

However, in reality, this program has experienced several problems. One of the problems in 2019 was the HOTS assessment got too difficult so that students felt overwhelmed in understanding the HOTS questions. This incident is a reflection for the teacher in developing HOTS questions following the principle of HOTS itself. So, the teacher plays an important role in the HOTS learning development process, especially in the HOTS assessment process. 
To find out the condition of the HOTS learning process in elementary school, the researcher interviewed the principal of Elementary School 36 Cengkeh named Mrs. Yurmailis, S.Pd. Based on the interview, HOTS learning has started in 2018 by combining the 2013 curriculum learning process. The principal stated that the school supports teachers to develop HOTS learning. However, there were several obstacles faced by teachers. The obstacles were related to the process of developing HOTS questions. The teacher assumes that the HOTS questions will overwhelm students in answering these questions and cause low achievement of students. The school principal also stated that the questions made by the teacher still used C1-C3. Therefore, the principal does not force the teacher to use HOTS-form questions in the learning process. She also stated that so far the teacher only knew HOTS from the guidance given without any socialization about HOTS learning classically. The school principal also stated that the government had conducted socialization by asking school representatives to attend the socialization. However, it did not give a significant impact because the socialization provided was in the classical seminar. The school delegates also did not have the extra knowledge obtained from the seminar. She also expressed his high hopes for the Primary School Teacher Education department, as an education partner for elementary schools in West Sumatra, to provide training on HOTS, especially in the process of preparing HOTS questions.

From the interview, it can be seen that there are problems faced by schools in making HOTS questions. The problem lies in the teacher's knowledge of HOTS questions. To find out the teacher's knowledge about HOTS, the researcher asked the principal for permission to give questions related to HOTS questions. Besides, the researcher team also asked the teacher to make HOTS questions based on the bloom taxonomy. Based on the evaluation, the teacher got an average score of 63.76, while the skill of making questions for the teacher got a score of 56.95. From the results of the evaluation, it can be concluded that the knowledge and skills of primary school teachers are still low in making HOTS questions.

This problem must be solved immediately to avoid problems in achieving the learning objectives. Based on the discussion from the team, what to do is to provide training to elementary school teachers in developing HOTS instruments in the learning process. This is also supported by the previous research that providing training can increase teacher knowledge in developing HOTS for elementary school students (Safi i, 2019). Therefore, this training aims to develop the ability of teachers to make HOTS questions for elementary school students.

\section{Methods}

This training held at Elementary School 36 Cengkeh with 15 participants. This activity consists of seminars and training methods. At the seminar, the teacher got knowledge on how to make HOT questions for elementary school students. This activity aims to provide elementary teachers about HOTS questions in the learning process. As for training, teachers try to make HOTS questions for elementary school students. To measure the success of the training, an evaluation conducted. The evaluation consists of an evaluation of conceptual understanding and skills. The training is successful if there is an increase in the teacher's knowledge regarding the material presented and get a score above 75 for skills assessment.

\section{Results and Discussion}

The discussion on this activity is divided into two general parts, namely:

\subsection{Seminar on Making HOTS Questions}

The seminar on making HOTS questions hosted by Mrs. Sherlyane Hendri, S.Pd., M.Pd. At the beginning of the seminar, Mrs. Sherlyane stated that there are still many elementary school teachers who got low-level thinking skills and the questions presented are not contextual questions. Mrs. Sherlyane stated that there are still many elementary school teachers who still make question theoretically and does not connect the learning process to students' real-life. This resulted in the evaluation process in primary schools only about understanding the material. Therefore, it is necessary to improve the ability of teachers in making HOTS questions.

Furthermore, Mrs. Sherlyane explained about HOTS. She stated that the HOTS question was a question used to measure and assess students' higher-order thinking skills. HOTS is not only memorizing, restating, 
or reciting questions but also connecting concepts, processing various information, looking for connections from various information, and analyzing ideas critically and creatively. However, what Ms. Sherlyane emphasized was that HOTS was not a difficult problem.

Mrs. Sherlyane stated that HOTS needed to be developed in Indonesia because of the demands of hard and soft skill development. In the future, education requires students to have hard skills and soft skills. She also stated that HOTS is necessary because of the demands of 21st-century skills. In the present and the future, students who can think critically, creatively, communicatively, and collaboratively are needed. Then Mrs. Sherlyane conveyed how the process of learning change from LOTS to HOTS learning. She said that the 2013 curriculum learning had the purpose of developing students' interests, talents, and potential so that they had good character and were supported by competent and literate traits. She also conveyed that each subject is related to competencies and contexts that can encourage students to have thinking skills from simple (LOTS) to higher-order thinking processes (HOTS). She said that learning activities had to change, from LOTS to HOTS. Therefore, in the end, HOTS became a student character. She affirmed learning at school must be able to produce graduates with character, competence, and literacy to be ready to face the challenges of the 21st century.

Furthermore, Mrs. Sherlyane explained the dimensions of the cognitive process by Bloom and Anderson's version. Bloom and Anderson divide six cognitive dimensions, namely remembering, understanding, applying, analyzing, evaluating, and creating. Remembering is a process of taking knowledge related to memory. Understanding is building the learning process through research, writing, and even pictures. Applying is executing according to the procedure in an unusual situation. Analyzing means dividing the material into sub-sections and finding the connection between these sections. Evaluating means making considerations according to agreed standards and criteria. Creating means forming the elements as a whole, rearranging these elements into a new structure.

Then Ms. Sherlyane explained the meaning of the cognitive process dimension by displaying the following picture:

Table 1 Image of cognitive dimensions

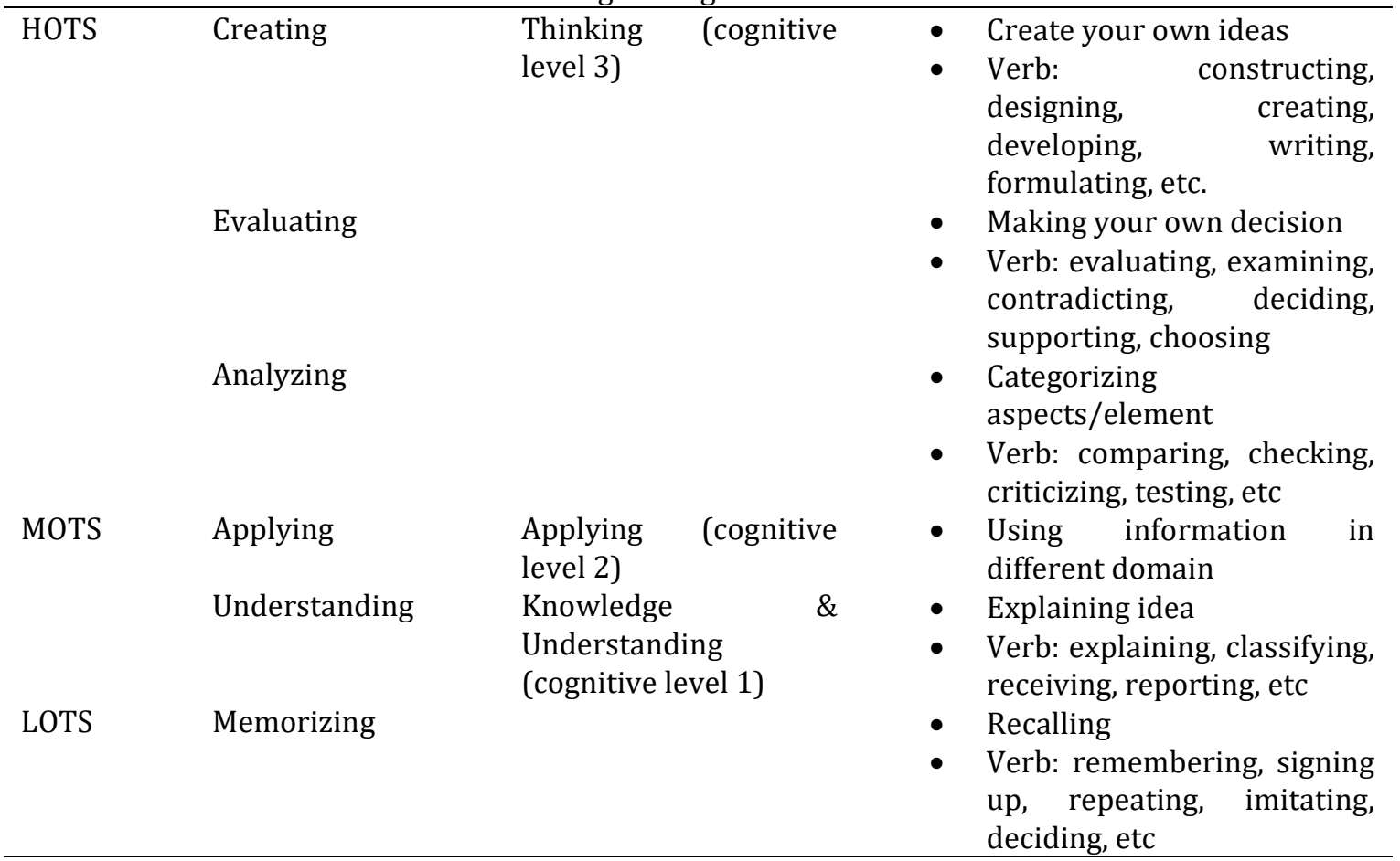

After explaining the cognitive dimensions, then Mrs. Sherlyane explained about the characteristics of HOTS questions. He said that HOTS questions have the characteristics of transferring one concept to another, processing and applying information, connecting different information, using the information to solve problems, and critically analyzing ideas and information. Then she gave examples of questions based on these characteristics as in the table below. 
Table 2 Example of questions

\section{Characteristic} features

transferring one concept to another

Processing and applying information.

Looking different information.

Using information to solve problems

\section{Questions}

5. Hasil dari $2 \frac{3}{5} \times 2,5: 75 \%=n$, maka $n=\ldots$.
A. $4 \frac{1}{3}$
B. $5 \frac{2}{3}$
C. $6 \frac{2}{3}$
D. $8 \frac{2}{3}$

a result of $23 / 5 \times 2,5: 75 \%=n$, then $n=$

6. Nenek membuat kunyit asem dengan perbandingan kunyit : gula $5: 3$. Jika kunyit digunakan $8 \mathrm{~kg}$ lebih banyak dari gula, maka gula yang dibutuhkan nenek ada ... .
A. $8 \mathrm{~kg}$
B. $12 \mathrm{~kg}$
C. $20 \mathrm{~kg}$
D. $32 \mathrm{~kg}$

Grandma makes tamarind turmeric with a 5: 3 ratio of turmeric : sugar. If Grandma uses turmeric $8 \mathrm{~kg}$ more than sugar, then the sugar needed by grandmother is

for 26. Perhatikan gambar!

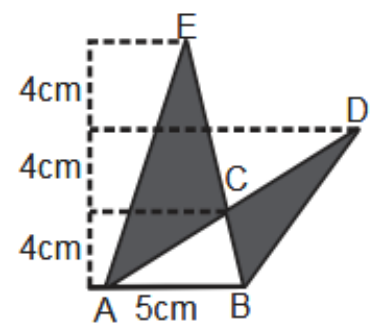

Luas daerah yang diarsir adalah ....
(A) $15 \mathrm{~cm}^{2}$
(C) $45 \mathrm{~cm}^{2}$
(B) $30 \mathrm{~cm}^{2}$
(D) $75 \mathrm{~cm}^{2}$

Look at the picture below!

The shaded area is......

32. Perhatikan gambar berikut !

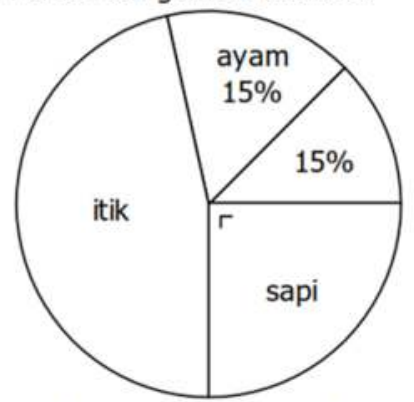

Jika ternak sapi 425 ekor ternak itik ada ... .
A. 255 ekor
B. 425 ekor
C. 765 ekor
D. 865 ekor

Look at the picture below! Chicken 15\% 


\section{Ducks}

Cows

Critically analyzing ideas and information

Critically analyzing ideas and information

If there are 425 cows, then ducks are

1. Hitunglah $1+2+3+\ldots+100$.

2. Jika $1^{2}+2^{2}+3^{2}+\ldots+11^{2}=506$, maka

hitunglah $2^{2}+4^{2}+6^{2}+\ldots+22^{2}$.

1. Count $1+2+3+\ldots+100$

2. If $1^{2}+2^{2}+3^{3}+11^{2}=506$, then count $2^{2}+4^{2}+6^{2}+\ldots+22^{2}$

The weight of item I and II is $8.6 \mathrm{~kg}$. The weight of item I and III is $7.2 \mathrm{~kg}$. The weight of item II and III is $5.4 \mathrm{~kg}$. Calculate the weight of item I, item II, and item III at once.
A. $10,6 \mathrm{~kg}$
B. $11,2 \mathrm{~kg}$
C. $11,4 \mathrm{~kg}$
D. $11,6 \mathrm{~kg}$

At the end of the activity, the teacher received an evaluation to find out the teacher's understanding of HOTS questions.

\subsection{Training on Making HOTS Questions}

This activity guided by Drs. Syafri Ahmad, Ph.D. At the beginning of the activity, Mr. Syafri explained the characteristics of HOTS questions. He conveyed that HOTS questions have the characteristic of measuring HOTS abilities by reducing aspects of remembering and understanding. HOTS questions must be based on contextual problems and HOTS questions must be interesting, unfamiliar, and new.

Mr. Syafri explained that there are challenges found in making HOTS questions. The first challenge is that it is difficult to describe indicators of competency achievement and indicators of questions. To answer this challenge, Mr. Syafri stated that it could be avoided by determining learning objectives, determining subject matter (factual, conceptual, procedural, metacognitive), determining learning steps, determining learning media and resources, and determining the form of assessment instruments. The second challenge is arranging the HOTS stimulus. There are 4 ways to arrange the HOTS stimulus, namely: a) Choose some information in the form of pictures, graphs, tables, discourses, etc. relating to a case. b) Stimulus should require the ability to interpret, connect, analyze, conclude, or create. c) Choose cases/problems that are contextual and interesting (current) to motivate students to read. Exceptions for the subject of Language, History may not be contextual. d) Directly related to the question (subject matter).

Then Mr. Syafri explained the steps to arranging HOTS questions, namely analyzing the Basic Competencies made by HOTS questions, compiling the question grid, choosing interesting and contextual stimulus, writing question items on the question card following the rules, and making scoring guidelines or answer keys. He also told that in preparing HOTS questions, it was necessary to pay attention to using realworld contexts, giving questions related to visual analysis, asking the reasons for the answers given, and using a variety of question forms.

After that Mr. Syafri described how to make HOTS questions and their examples and asked the participants to make questions too. At the end of the activity, the questions made by the participants were collected as evaluation material.

After the training, the evaluation of the teacher's knowledge and skills conducted. The result is the evaluation of teacher knowledge get a score of 87, 65 and for teacher skills get a score of 85.35. The summary of the training results are in the table below. 
Table 3 Summary of training results

\begin{tabular}{lll}
\hline Aspect & Early ability & Final ability \\
Knowledge & 63,76 & 87,65 \\
Skills & 56,95 & 85,35 \\
\hline
\end{tabular}

The table shows an increase between aspects. To make it easier to see the presentation, it can be seen in the graph below:

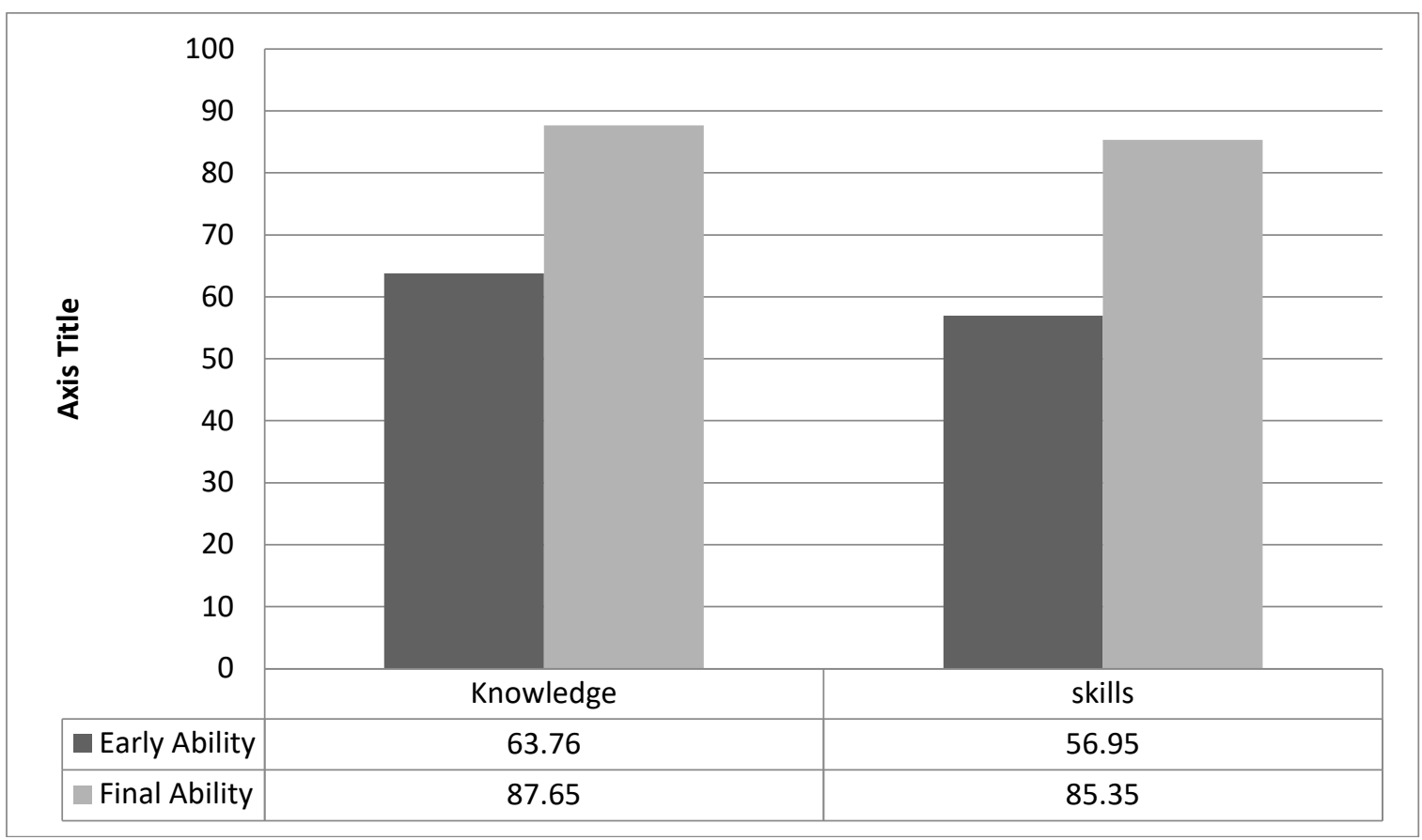

Fig. 1 of Improvement of teacher knowledge and skills.

This figure explains that there was an increase in the teacher's knowledge and skills in making HOTS questions. From the score obtained, each aspect gets a score above 75.00. This proves that the training carried out has achieved the indicators of success. The training given to elementary school teachers regarding HOTS is the right step to be implemented. If the teacher is unable to make the correct HOTS questions, the teacher will get invalid data regarding the HOTS level of elementary school students. If this happens continuously, it will affect the achievement of learning objectives as a whole.

This training was successfully implemented due to several factors. The first factor is the teacher's motivation to participate in this training. Motivation has a strong relationship with learning achievement (Ardiana, 2017; Hendri et al, 2019). Teachers are actively involved during the training process. Activeness in the learning process also affects learning achievement (Hendri et al, 2019; Astuti, 2017). The teachers participate actively in the activity. Besides, this activity succeeds because of the strong cooperation between teachers and mentors and fellow teachers. Cooperation is one way to improve the quality of learning (Nurmawati et al, 2012; Wulandari et al, 2015). These factors are what lead to training achieving indicators of success.

\section{Conclusion}

The results of this training concluded that there was an increase in the knowledge and ability of elementary school teachers in making HOTS questions. 


\section{Acknowledgment}

I am very grateful for Padang State University for funding all these activities and we also thank all the partners involved in this training.

\section{References}

Ahmad, S., Kenedi, A. K., \& Masniladevi, M. (2018). Instrumen Hots Matematika Bagi Mahasiswa PGSD. Jurnal PAJAR (Pendidikan dan Pengajaran), 2(6), 905-912.

Ahmad, S., Kenedi, A. K., Ariani, Y., \& Sari, I. K. (2019, October). Instrument higher order thinking skill design in course high-class mathematics in elementary school teacher of education departement. In Journal of Physics: Conference Series (Vol. 1321, No. 2, p. 022129). IOP Publishing.

Ahmad, S., Prahmana, R. C. I., Kenedi, A. K., Helsa, Y., Arianil, Y., \& Zainil, M. (2017, December). The instruments of higher order thinking skills. In Journal of Physics: Conference Series (Vol. 943, No. 1, p. 012053).

Ardiana, T. E. (2017). Pengaruh motivasi kerja guru terhadap kinerja guru akuntansi SMK di Kota Madiun. Jurnal Akuntansi dan Pajak, 17(02).

Ariyana, Y., Bestary, R., \& Mohandas, R. (2018). Buku Pegangan Pembelajaran Berorientasi pada Keterampilan Berpikir Tingkat Tinggi. (Jakarta: Direktorat Jenderal Guru dan Tenaga Kependidikan Kementerian Pendidikan dan Kebudayaan Hak).

Astuti, C. C. (2017). Analisis korelasi untuk mengetahui keeratan hubungan antara keaktifan mahasiswa dengan hasil belajar akhir. JICTE (Journal of Information and Computer Technology Education), 1(1), 1-7.

Hendri, S. S., Hendri, S., Kenedi, A. K., Helsa, Y., \& Anita, Y. (2019, December). Elementary School Teacher Ability in Using Application Technology for Mathematics Learning Assessment in the 2013 Curriculum. In 5th International Conference on Education and Technology (ICET 2019). Atlantis Press.

Hendri, S., Helsa, Y., Anita, Y., \& Kenedi, A. K. (2019). Pelatihan Penilaian Otentik dan Penggunaan Aplikasi Penilaian Kurikulum 2013 untuk Sekolah Dasar. Jurnal Halaqah, 1(4), 446-459.

Kenedi, A. K. (2018). Desain Instrument Higher Order Thingking Pada Mata Kuliah Dasar-Dasar Matematika Di Jurusan PGSD. AR-RIAYAH: Jurnal Pendidikan Dasar, 2(1), 67-80.

Kenedi, A. K., Ahmad, S., Sofiyan, T. A. N., \& Helsa, Y. The Mathematical Connection Ability of Elementary School Students in the 4.0 Industrial Revolution Era.I nternational Journal of Innovation, Creativity and Change, Vol. 5, No. 5, pp. 458-472, 2019.

Kenedi, A. K., Helsa, Y., Ariani, Y., Zainil, M., \& Hendri, S. (2019). Mathematical Connection of Elementary School Students to Solve Mathematical Problems. Journal on Mathematics Education, 10(1), 69-80.

Merta Dhewa, K., Rosidin, U., Abdurrahman, A., \& Suyatna, A. (2017). The development of Higher Order Thinking Skill (Hots) instrument assessment in physics study. IOSR Journal of Research \& Method in Education (IOSR-JRME), 7(1), 26-32.

Nurnawati, E., Yulianti, D., \& Susanto, H. (2012). Peningkatan kerjasama siswa SMP melalui penerapan pembelajaran kooperatif pendekatan think pair share. UPEJ Unnes Physics Education Journal, 1(1). 
Pratama, G. S., \& Retnawati, H. (2018, September). Urgency of higher order thinking skills (HOTS) content analysis in mathematics textbook. In Journal of Physics: Conference Series (Vol. 1097, No. 1, p. 012147). IOP Publishing.

Priyani, H. A., \& Ekawati, R. (2018, January). Error analysis of mathematical problems on TIMSS: A case of Indonesian secondary students. In IOP Conference Series: Materials Science and Engineering (Vol. 296, No. 1, p. 012010). IOP Publishing.

Safi' 'i, I., \& Amar, F. (2019). Pelatihan Penyusunan Instrumen Evaluasi Berstandar HOTS bagi Guru-Guru SD di Wilayah Banyudono. Abdimas Dewantara, 2(2), 149-157.

Widana, I. W. (2017). Higher order thinking skills assessment (HOTS). JISAE, 3(1), 32-44.

Wulandari, B., Arifin, F., \& Irmawati, D. (2015). Peningkatan kemampuan kerjasama dalam tim melalui pembelajaran berbasis lesson study.Elinvo (Electronics, Informatics, and Vocational Education), 1(1), 9-16.

Yuliati, S.R and I. Lestari, I. (2018). Higher-Order Thinking Skills (Hots) Analysis of Students in Solving Hots Question In Higher Education. Perspektif Ilmu Pendidikan, 32(2), 181-188.

Zaharin, N. L., Sharif, S., \& Mariappan, M. (2018). Computational Thinking: A Strategy for Developing Problem Solving Skills and Higher Order Thinking Skills (HOTS). Int. J. Acad. Res. Bus. Soc. Sci, 8 , 1265-1278. 